OCCASIONAL PAPER

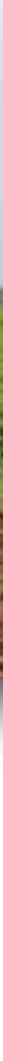

\title{
Potential land use competition from first-generation biofuel expansion in developing countries
}

George C. Schoneveld

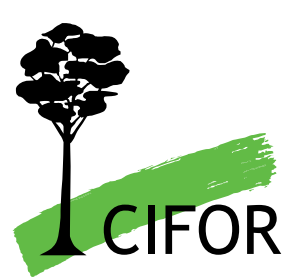





\section{Potential land use competition from first-generation biofuel expansion in developing countries}

George C. Schoneveld 
Occasional Paper 58

(c) 2010 Center for International Forestry Research

All rights reserved

ISBN 978-602-8693-31-8

Schoneveld, G.C. 2010 Potential land use competition from first-generation biofuel expansion in developing countries. Occasional paper 58. CIFOR, Bogor, Indonesia.

Cover photo: Large-scale jatropha plantations in Ghana @ George C. Schoneveld/CIFOR

This publication was produced with the financial assistance of the European Union, under the project, 'Bioenergy, sustainability and trade-offs: Can we avoid deforestation while promoting bioenergy?' European Community Contribution Agreement EuropeAid/ENV/2007/143936/TPS.

The project aims to contribute to sustainable bioenergy development that benefits local people in developing countries, minimises negative impacts on local environments and rural livelihoods, and contributes to global climate change mitigation. The project will achieve this by producing and communicating policy relevant analyses that can inform government, corporate and civil society decision making related to bioenergy development and its effects on forests and livelihoods. The project is managed by CIFOR and implemented in collaboration with the Council on Scientific and Industrial Research, South Africa; Joanneum Research, Austria; the Universidad Autónoma de México; and the Stockholm Environment Institute, Sweden. The views expressed herein can in no way be taken to reflect the official opinion of the European Union.

\author{
CIFOR \\ Jl. CIFOR, Situ Gede \\ Bogor Barat 16115 \\ Indonesia \\ $\mathrm{T}+62(251) 8622-622$ \\ $F+62(251) 8622-100$ \\ E cifor@cgiar.org
}

\title{
www.cifor.cgiar.org
}




\section{Contents}

Key messages $\quad 1$

1. Introduction 1

2. Enhancing energy security by incorporating biofuels into the energy mix 2

3. Developing country perspectives on biofuel development 4

4. Land suitable for biofuel feedstock production 5

5. Potential future threat to forested and agricultural land 6

5.1 Oil palm expansion in Asia 8

$\begin{array}{ll}5.2 \text { Soya expansion in South America } & 11\end{array}$

$\begin{array}{ll}5.3 \text { Jatropha expansion in Africa } & 12\end{array}$

$\begin{array}{ll}5.4 \text { Land requirements for biofuel blending in developing countries } & 13\end{array}$

$\begin{array}{ll}\text { 6. Conclusion } & 17\end{array}$

$\begin{array}{lr}\text { Endnotes } & 19\end{array}$

$\begin{array}{lr}\text { References } & 20\end{array}$ 


\section{List of figures and tables}

\section{Figures}

1. Area of suitable land not classified as forested or cultivated land for selected biofuel feedstocks

2. Competing uses for suitable land in Asia 7

3. Competing uses for suitable land in Africa 7

4. Competing uses for suitable land in South America 7

5. Competing land uses for suitable land worldwide 9

6. Average annual increase in area harvested of major feedstocks (2000-2008)

7. Percentage of suitable land not classified as forest or cultivated land (for selected feedstocks) required to substitute biodiesel and ethanol produced from key feedstocks for $10 \%$ of petroleum consumption in the transportation sector

\section{Tables}

1. Vulnerability of net oil-importing regions and countries to oil price shocks 2

2. Biofuel production in 2009

3. Scenarios for $10 \%$ petrodiesel substitution with biodiesel in the transportation sector for selected countries

4. Scenarios for $10 \%$ gasoline substitution with ethanol in the transportation sector for selected countries 


\section{Key messages}

- Developing countries have a competitive advantage for cultivating biofuel feedstock: $75-95 \%$ of total available and agro-ecologically suitable land is located in developing countries.

- In Asia, almost all suitable land is classified as agricultural or forested, creating severe land use competition. South America and Africa have the largest areas of suitable land available for biofuel feedstock production, but most is under competing uses.

- The risks of deforestation and conversion of agricultural land are high if large-scale biofuel development is not effectively regulated.This could lead to loss of vital ecosystem services and undermine food security and rural development.

- Globally, the threat of land use competition is especially severe for oil palm and sugarcane cultivation.

- International demand for food and feed use of biofuel feedstock - rather than biofuels-has contributed most significantly to adverse impacts of land use change. This is especially the case for oil palm expansion in Southeast Asia and soya expansion in South America.

- External demand for biofuels in industrialised countries will likely be a key driver of biofuel expansion during the 2010s. This could incite direct land use change in developing countries that capitalise on new trade opportunities; however, areas of land required to service these markets are relatively small (6-7 million ha).

- In most developing countries, biofuel blending targets can be met using harvests from one medium to large plantation.

- In most developing countries, high dependency on imported fossil fuels creates significant macro-economic instability. An energy security agenda should therefore be prioritised, before actively targeting export markets with domestically produced biofuels. This is especially relevant where only small areas of land are both suitable and genuinely available.

\section{Introduction}

The global production of biofuels has almost tripled since 2005 , driven largely by a combination of concerns, especially in industrialised countries, about overdependency on imported fossil fuel products and the impacts of climate change. For many developing countries, this trend is creating new opportunities. It is argued that developing countries could be significantly more competitive in producing biofuels than industrialised countries, due to relatively low costs of production and the availability of cheap agro-ecologically suitable land for the cultivation of biofuel feedstocks. Although this trend could provide developing countries with much-needed international trade and investment, it does pose a number of challenges. This paper focuses on a key challenge: the potential threat that biofuel feedstock expansion poses to sustainable land use in developing countries. The paper aims to illustrate the nature, extent and impact of land use competition associated with the expansion of biofuel feedstock cultivation, especially as such expansion could potentially contribute to deforestation and conversion of agricultural land.

The next 2 sections discuss the trends and prospects for biofuel development, and the potential development implications these may have for developing country economies. The subsequent section assesses the challenges sector development may raise when converting existing land uses to biofuel feedstock cultivation. It draws on existing land use and crop suitability data to illustrate what types of land use competition could be anticipated in different regions. It then explores the potential pathways for and implications of land conversion to biofuel feedstock cultivation by reviewing historical evidence from the different eco-regions. Finally, this paper analyses the likely extent of these threats by assessing the potential magnitude of demand for land resources in a situation where countries decide to commit to developing a domestic biofuel industry. 


\section{Enhancing energy security by incorporating biofuels into the energy mix}

Fossil fuels (including crude oil, petroleum products, natural gas and electricity generated from these sources) are the most important global source of energy, accounting for approximately $62 \%$ of total energy consumption in 2006 (IEA 2010). The production of oil, however, is heavily concentrated in a few countries-only 41 countries meet their oil consumption through production. In 2008, 10 of those countries were responsible for $52 \%$ of total crude oil production (BP 2009). The net oil-importing countries, on the other hand, met $67 \%$ of their oil needs through imports. Africa in particular is highly dependent on imported oil, with 36 out of 54 countries importing $100 \%$ of their oil requirements in 2008. Dependency on imported oil is also acute in Central America, with only one country being a net oil exporter (calculated from EIA 2010).

This high degree of dependency on foreign energy sources can have high economic costs. The relative economic costs of dependency on imported oil for different regions have been calculated for 2 points in time, over which oil prices rose by $142 \%$, from a
2004 average of US $\$ 38.30$ per barrel to an average of US $\$ 92.80$ per barrel in 2008 (Table 1). By 2008 , the value of net oil imports had increased by almost US $\$ 860$ billion over 2004 levels for net oil-importing countries. In South Asia and subSaharan Africa, the oil price rise was equivalent to a loss of GDP of $2.6 \%$ and $2.8 \%$, respectivelyconsiderably more than the global average of $1.2 \%$. This illustrates the macroeconomic implications for many poor oil-importing countries as oil prices rise. Heavy reliance on imported oil significantly increases vulnerability to oil price fluctuations. This can have several consequences, such as a reduction in foreign exchange reserves, decrease in output or increase in external debt.

The poorest countries in the world are especially vulnerable to oil price shocks, with a significant inverse correlation between relative economic costs of oil imports and GDP per capita $(P<0.01)$ (author's calculations). Countries with GDP per capita below US $\$ 1000$ experience the highest rates of dependency (Table 1). Furthermore, the more dependent a country is on imported oil, the higher its external debt position $(P<0.01)$ (author's calculations), illustrating the relatively low capacity of poor countries to cope with and respond to oil prices shocks. Thus, diversifying energy sources

Table 1. Vulnerability of net oil-importing regions and countries to oil price shocks

\begin{tabular}{|c|c|c|c|}
\hline & \multicolumn{2}{|c|}{ Net import/GDP (\%) } & \multirow{2}{*}{$\begin{array}{c}\text { Change from } 2004 \text { to } 2008 \\
(\%)\end{array}$} \\
\hline & 2004 & 2008 & \\
\hline \multicolumn{4}{|l|}{ Region or country } \\
\hline Africa & 2.2 & 4.9 & 124.7 \\
\hline Asia & 2.2 & 4.0 & 79.7 \\
\hline Latin America & 1.6 & 1.5 & -2.4 \\
\hline Europe & 1.2 & 2.2 & 82.1 \\
\hline USA & 1.4 & 2.6 & 78.7 \\
\hline \multicolumn{4}{|l|}{ By income group in US\$ } \\
\hline$<\$ 1000$ per capita & 3.3 & 5.9 & 78.3 \\
\hline$\$ 1000-3000$ per capita & 2.1 & 3.1 & 48.6 \\
\hline$\$ 3000-10000$ per capita & 1.9 & 2.3 & 22.8 \\
\hline > \$10 000 per capita & 1.4 & 2.6 & 81.4 \\
\hline All net oil-importing countries & 1.6 & 2.8 & 76.5 \\
\hline
\end{tabular}

Source: Derived from EIA (2010), World Bank (2010)

a. Vulnerability is calculated by multiplying the annual supply deficit (EIA 2010) by the average Brent oil spot price, and dividing by the GDP (at current US\$ value) for the given year (World Bank 2010). 
Table 2. Biofuel production in 2009

\begin{tabular}{|c|c|c|c|}
\hline Region & $\begin{array}{l}\text { Fuel ethanol } \\
\left(\text { ('000 litres }^{\mathrm{a}}\right)\end{array}$ & $\begin{array}{l}\text { Biodiesel } \\
\text { ('000 litres) }\end{array}$ & $\begin{array}{l}\text { Total biofuels } \\
\text { ('000 litres) }\end{array}$ \\
\hline Middle East & 0 & 0 & 0 \\
\hline Africa & 24373 & 5165 & 29537 \\
\hline Eurasia & 75439 & 220515 & 295955 \\
\hline Asia and Oceania & 3188362 & 2235568 & 5423930 \\
\hline Europe & 3599624 & 10016621 & 13616245 \\
\hline Central and South America & 27648180 & 3361789 & 31009969 \\
\hline North America & 42489427 & 2044556 & 44533983 \\
\hline World total & 77025405 & 17884214 & 94909619 \\
\hline
\end{tabular}

Source: EIA (2010)

a. Converted from gallons per day

and developing alternative sources domestically are critically important, especially for least developed countries where the relative costs of oil dependency and the opportunity costs of federal funds (considering high poverty rates) are especially high.

Many countries have promoted biofuels as a substitute for oil consumption, and hence as a suitable alternative to many fossil fuel products. Biofuels can generally be blended by up to $10 \%$ with petroleum products without engine modification. The technologies for flex fuel vehicles have been sufficiently developed to enable adoption of even higher blending ratios. Although the transportation sector has typically been the target of biofuel incorporation, biofuels can also be used to generate electricity and for household use (e.g. for cooking and lighting).

Although Brazil and the USA have promoted the production of biofuels since the oil crisis of the 1970 s and early 1980s, it is only since the recent oil crisis and with increasing interest in climate change mitigation that renewable energy in general and biofuels in particular have become an important global policy concern. Despite this interest in the sector, production to date is limited. In 2009, approximately 95 billion L of biofuels was produced, $81 \%$ of which was bioethanol and $19 \%$ biodiesel (Table 2). This equates to 53.3 million tonnes of oil equivalent (toe) ${ }^{1}$ - not more than $0.4 \%$ of the world's total primary energy supply. Moreover, production is still dominated by Brazil and the USA, collectively accounting for $75 \%$ of global production. Although Africa in particular is grappling with high energy insecurity, its production of biofuels is negligible.

The production volume of biofuels is, however, expected to increase dramatically during the 2010s. For example, in the 2009 International Energy Outlook report (EIA 2009), it is forecast that under the reference scenario (assuming moderate oil prices) annual biofuel production will reach 226 billion L by 2020 . The OECD-FAO (2010) estimate that by 2019 annual production will have increased to approximately 200 billion L per year; in their reference scenario, it is assumed that large emerging markets, such as India, China and Brazil, will be able to meet most of their demand through domestic production. The European Union (EU-27) and the USA, on the other hand, are projected to become the largest biofuel-importing markets, as domestic production will not be sufficient to meet demand. The OECD-FAO report projects that, by 2019 , the USA will need to import more than 10.8 billion L of biofuels (approximately $15.1 \%$ of total domestic production) and the EU almost 7.1 billion L (18.4\% of total domestic production). Although FAPRI (2010) assumes similar market configurations, it projects more modest import volumes by the USA and EU, with projected annual net imports amounting to 9.8 billion L and 4.6 billion L, respectively, by $2019 .{ }^{2}$ However, the two reports share the assumption that over the projection period biofuel consumption will be driven largely by policy mandates rather than by markets (thus limiting the correlation between oil 
prices and biofuel prices). This assumption appears to be widely shared (Kojima and Johnson 2005; FAO et al. 2008; Peters and Thielmann 2008; USDA FAS 2009a; DEFRA 2010), as biofuels are unlikely to be able to compete with fossil fuels in most countries at current and projected oil prices without some form of government support.

\section{Developing country perspectives on biofuel development}

In the more industrialised OECD countries in particular, ${ }^{3}$ increasing the incorporation of biofuels into the domestic energy matrix has become an important policy objective. Most OECD countries have thus adopted policies and strategies to incentivise the domestic consumption and production of biofuels through, for instance, the mandatory incorporation of biofuels (typically complemented by sectoral subsidies, pricing controls and/or tax credits/exemptions). Whereas the pursuit of energy sovereignty is often a principal driver of government intervention in the sector, many other (at times divergent) objectives are shaping the policy discourse. These objectives include climate change mitigation, agricultural and rural development and international trade. The EU in particular is strongly committed to biofuels from a climate change mitigation agenda (as is evident from the EU Renewable Energy Directive), and the USA from an energy security agenda; developing countries are (in addition to reducing dependence on imported oil) increasingly embracing the economic opportunities that new investments and the opportunity of servicing new export markets could create (FAO-GBEP 2007).

\footnotetext{
Although almost all the OECD countries have formulated biofuel policies, or at least imposed biofuel incorporation targets, only a small proportion of non-OECD countries have made any regulatory provision for biofuel development (see REN21 2009 for an overview). The largest biofuel markets outside the OECD are typically those with strong government commitment and support for developing domestic biofuel markets, often grounded in the objective of enhancing energy security. These countries include Brazil, Colombia, Argentina, India, China, Mozambique
}

and Thailand, some of which have developed biofuel markets that are not only meeting domestic demand but are also servicing export markets. Although government incentives have been instrumental in driving sector development in these countries, there is an increasing number of countries where the sector is developing without any specific government intervention. For example, some-particularly African countries such as Ghana, Madagascar, Zambia and Tanzania-have experienced a surge in biofuel-related investments without any specific policies or government strategies to propel sector development. In these cases, the renewed global interest in biofuels has attracted private, often foreign, companies seeking to capitalise on new market opportunities by gaining access to the relatively cheap and abundant agro-ecologically suitable lands that are potentially available in these countries.

Key stakeholders in numerous developing countries are thus increasingly starting to recognise the economic opportunities that this biofuel trend could create, and the potential competitive advantage in strategic resources that they could exploit. In particular, it is perceived as an opportunity to bring in much-needed foreign exchange earnings and foreign investment, which in turn could further contribute to rural development through the upgrading of the agriculture sector in general and engendering potentially valuable occupational shifts. This comes at a time when most governments in developing countries are progressively becoming more liberal and accommodating towards foreign direct investment (FDI), as part of broader development strategies. Accordingly, many governments have sought to enhance their attractiveness as an FDI destination by enacting investment policies that provide for a host of incentives to prospective investors, for instance in the form of tax and duty exemptions, freedom of international capital flows and investor support services. Although such incentives create an environment conducive to FDI, few of these countries have enacted policies to promote the domestic incorporation of biofuels or other means to regulate sector development (e.g. sustainability standards), which in turn could have negative implications for sustainable land use. 
In the future, as more developing countries are expected to establish dedicated biofuel policies and strategies, strongly dualistic objectives will likely be pursued, as has been apparent from ongoing dialogues. On the one hand, there are strong incentives to promote domestic uptake of biofuel products (to enhance energy security), whereas on the other hand, there is a strong desire to embrace trade and investment opportunities. There is a risk, however, that these objectives might conflict as a deregulated environment for foreign investment undermines the reduction of energy dependency. This would particularly be the case when foreign biofuel companies are not required or incentivised to service domestic markets, and instead are unrestricted in selling opportunistically and/or entering into foreign off-take agreements.

\section{Land suitable for biofuel feedstock production}

The growing demand for biofuels worldwide raises the challenge of sourcing large areas of land for the production of feedstock. This is especially the case where developing countries are seeking to exploit trade and investment opportunities that may place considerably more pressure on finite land resources than if energy security were the sole policy objective.
Land suitability and availability assessments have been widely used as a tool for targeting areas for biofuel feedstock production that enable optimal yields whilst minimising the social and environmental costs of land use change. Suitability assessments provide an indication of where different biofuel crops can be cultivated, generally based solely on agronomic potential (maximum obtainable crop and biomass yields based on climate, soil and terrain conditions). ${ }^{4}$ Land availability, on the other hand, goes beyond agronomic considerations to other aspects of feasibility, such as competing land uses and land cover. In assessing the potential of different world regions and landscapes for the expansion of biofuel feedstock cultivation to meet global demand, it is therefore important to consider both these dimensions (i.e. suitability and availability). The areas (by region) that may be considered to be both suitable and potentially available are shown in Figure 1; these are identified by subtracting the area of suitable land classified as having competing uses (e.g. forested and cultivated land) from the total area of suitable land (adapted from Fischer et al. 2009). Suitable land not classified as cultivated or forested is typically grassland, shrubland or sparse woodland. ${ }^{5}$ As these types of land often provide fewer environmental services than forested lands and are under less intense anthropogenic use than cultivated land, the consequences of land

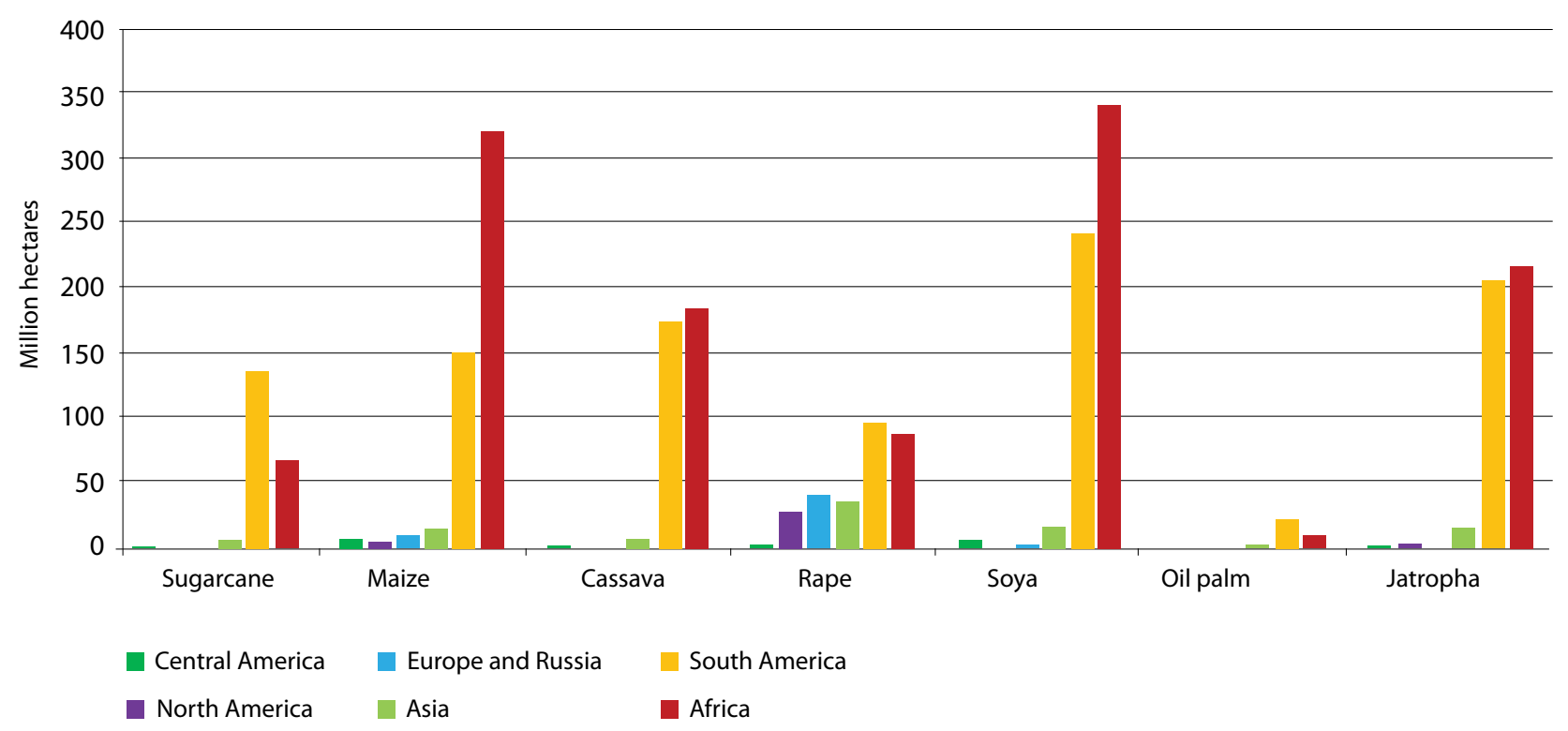

Figure 1. Area of suitable land not classified as forested or cultivated land for selected biofuel feedstocks 
conversion to feedstock cultivation will in many cases be not be extensive. As can be observed, Africa and South America have some of the largest areas in the world considered both suitable and potentially available for the cultivation of biofuel feedstock. In terms of area, maize, soybean, cassava and jatropha cultivation offer the greatest promise in both Africa and South America. In total, approximately $75-95 \%$ of suitable and potentially available land (depending on feedstock) is located in developing countries.

For most feedstocks, only $20-30 \%$ of suitable land can in fact be classified as potentially available, with most suitable land classified as either cultivated or forested. In Asia, less than $10 \%$ of suitable land is considered potentially available for most feedstocks, whilst in Africa and South America potential availability ranges from $10 \%$ to $50 \%$ of suitable land, depending on the feedstock. In the case of sugarcane and oil palm, particularly large proportions of suitable land are located in forested areas-approximately $54 \%$ and $79 \%$ of suitable land, respectively. Globally, this equates to 575 million ha of the 1.06 billion ha of areas suitable for sugarcane and 478 million ha of the 605 million ha of areas suitable for oil palm. However, the nature of land use competition differs greatly by region (Figures 2, 3 and 4). Whereas in South America and Africa the most significant land use competition is with forests, in Asia it is mostly cultivated land that competes with feedstock-suitable areas. In Asia, for example, for most feedstocks, between $65 \%$ and $85 \%$ of suitable land is classified as cultivated land. Oil palm, however, is an exception, with almost $46 \%$ of suitable areas classified as forested. Whereas a total area of 94 million ha is suitable for oil palm cultivation in Asia, 44 million ha is forested and 45 million ha cultivated, leaving (theoretically) at most 5 million ha without competing uses.

\footnotetext{
Although Africa and South America potentially have relatively large areas of suitable and available land with comparatively low identified land use competition, these might not be the most convenient or economically appropriate lands for producers. For example, companies could disproportionately seek out agricultural lands as these are often located along key transportation routes, in the vicinity of important market
}

centres and in the most fertile areas. Similarly, investors could seek out forested land because of low population densities and high agro-ecological suitability and in order to generate a supplementary income from the sale of forest products. This suggests that in the absence of effective control mechanisms, some producers might nonetheless be compelled to convert forests and agricultural lands as opposed to targeting land that is actually available.

\section{Potential future threat to forested and agricultural land}

These data on competing uses of suitable land offer valuable insights into the relative productivity of the different feedstocks in cultivated and forested areas. This in turn enables us to assess the relative risk of land use change in the absence of mechanisms to effectively regulate land conversion to biofuel feedstock. Unrestrained land use change for biofuel feedstock could lead to a loss of biodiversity and forest cover, in turn detracting from the potential contribution of biofuels to improving the carbon balance. Furthermore, the displacement of agriculture could increase food and income insecurity, especially in Africa, where most countries are net food importers and most people are net food buyers, and where there are some of the highest rates of malnutrition in the world (Aksoy and IsikDikmelik 2008 FAO et al. 2008; FAO 2009). Here, conversion of agricultural land could potentially have dire humanitarian implications.

From the data presented in the preceding section, we can generalise that the overall risk of conversion of agricultural land is relatively high in Asia, whereas in South America and Africa it is forests that are especially threatened by biofuel expansion. However, these regional generalisations mask the heterogeneous realities within regions. For example, as shown in Figure 5, biofuel feedstocks are particularly productive in the main tropical rainforest biomes of the Congo Basin (e.g. Republic of the Congo, Democratic Republic of the Congo and Cameroon), the Amazon Basin (e.g. Brazil, Colombia and Peru) and Southeast Asia (particularly Indonesia and Papua New Guinea), and in miombo woodlands (e.g. Mozambique, Tanzania and Zambia). Similarly, in the case of agricultural land, large areas of South Asia, Indochina, the Sahel, southeast Brazil and 


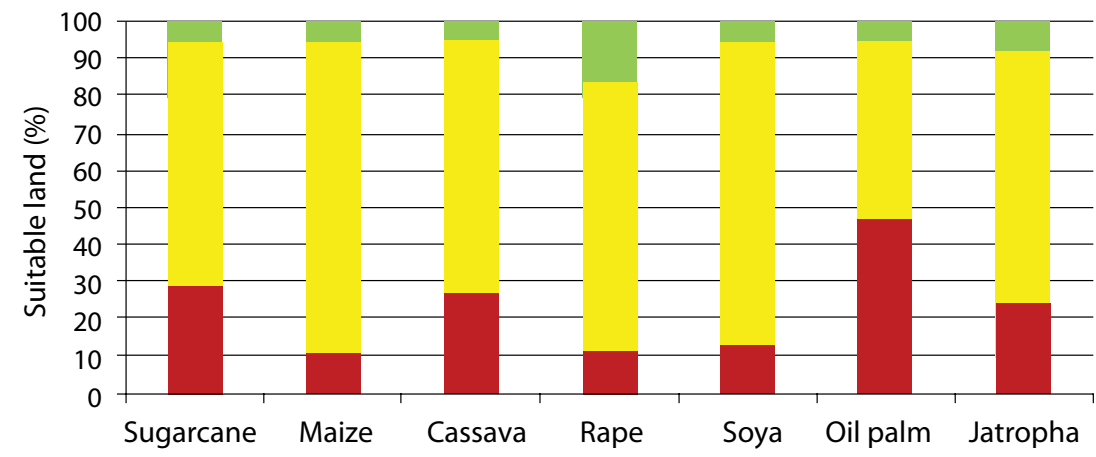

Other

Cultivated

Forest

Figure 2. Competing uses for suitable land in Asia

Source: Derived from Fischer et al. 2009

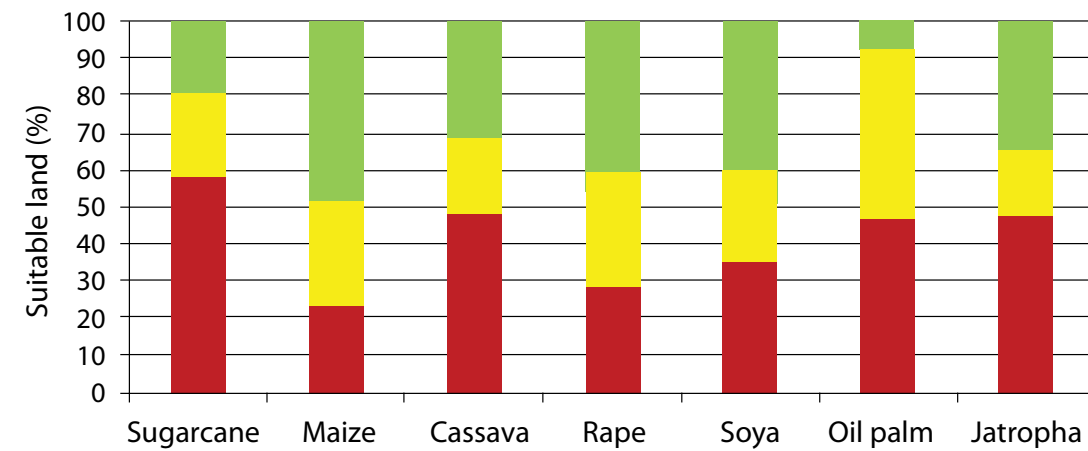

Other

Cultivated

Forest

Figure 3. Competing uses for suitable land in Africa

Source: Derived from Fischer et al. 2009

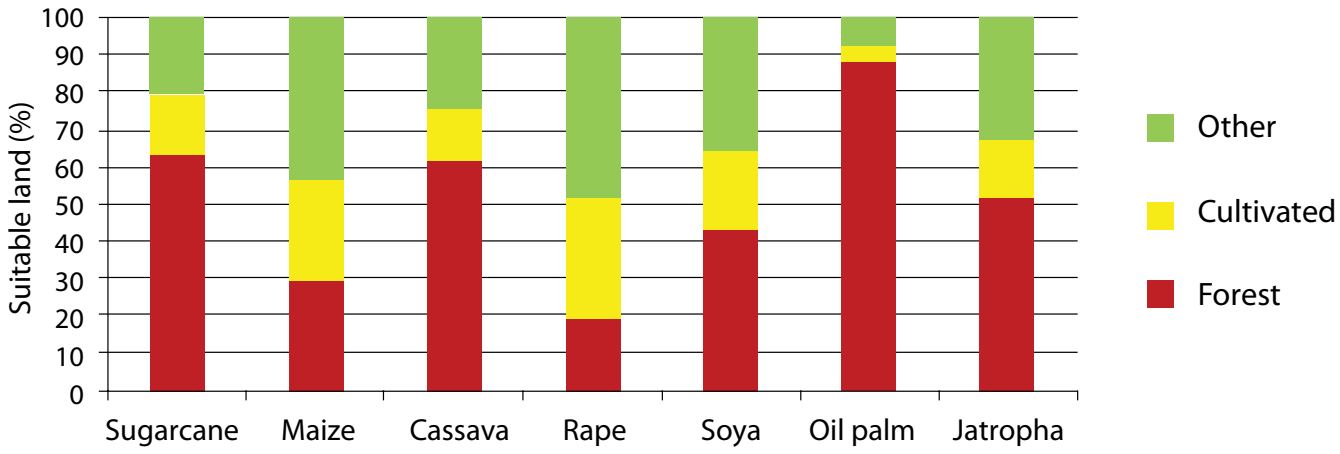

Figure 4. Competing uses for suitable land in South America

Source: Derived from Fischer et al. 2009

northern Argentina are already occupied for agricultural purposes. Land that is potentially available for biofuel feedstock cultivation is often highly geographically dispersed and fragmented, illustrating the challenge of seeking out large contiguous areas of land (often preferable to enable economies of scale) without inciting land use competition. Moreover, in practice, few lands that are classified as available are truly available, as they are often under complex and overlapping systems of land use and rights (see Box 1 for a more detailed discussion). Therefore, the type of land availability assessment conducted here, based on broad land use classifications that often do not capture local realities, needs to be complemented by detailed on-the-ground analysis to determine the actual 


\section{Box 1. Is 'available' land really available?}

Land classified as 'available' is typically considered to be 'marginal', 'degraded', 'idle', 'abandoned,' 'unproductive' or 'unutilised'. This raises 2 concerns. The first is that the poor definition of concepts leaves them open to abuse by decision makers or companies pressured to identify suitable areas for development. The second concern is that these concepts are relative to one's perspective. Lands that might be considered 'marginal', 'degraded' or 'unproductive' by one person or use might be considered productive for other purposes - such as the provision of fuelwood, non-timber forest products or grazing in secondary forests or shrubland. Land considered 'idle', 'abandoned' or 'underutilised' by government agencies accustomed to viewing landscapes in terms of their permanent features and documented ownership might be actively used by shifting agriculturalists and pastoralists (Cotula et al. 2008; Sugrue 2008), provide essential subsistence or 'safety net' functions to women and the poor (Rajagopal and Zilberman 2007; Rossi and Lambrou 2008) or be under complex customary systems of land use that are difficult to 'read' by outsiders. For instance, land that may be legally categorised as state or public land may be intensively used by groups not enjoying formal tenure rights to these lands. Especially in Africa, where no more than $10 \%$ of land is formally registered (Deininger 2003), the existence of formal property rights is not an appropriate variable for assessing land availability.

The land uses described here are often not accurately captured in land use classifications either. For instance, the FAO classification system (FAO 2010), on which the 'cultivated land' classification used in the preceding section is based, does not consider land to be under agricultural use when it is left fallow for more than 5 years. However, in many systems of shifting cultivation, cropping cycles can be considerably longer. Consequently, land might be considered available whilst being an integral part of a farming system. Furthermore, land that formerly had anthropogenic land uses, but does not any longer, might be considered available despite longterm processes of natural regeneration taking place. Although the range of environmental services offered by this land might be negligible at a particular point in time, these may over time eventually exceed those offered by large-scale monoculture if left undisturbed. As one report puts it: 'The evidence suggests that there really are very few genuinely "marginal" lands, or at least none that conform to the abandoned, empty and useless land of our imagination' (Anonymous 2008, p. 1). Clearer definitions of concepts are therefore required 'to avoid allocation of lands on which local user groups depend for livelihoods' (Cotula et al. 2008, p. 3).

degree of potential land use competition. As almost all land is under some form of use, and is thus rarely genuinely available, a clearer consensus on what type of land would be most appropriate for conversion is much needed.

Historical data on the geographies of feedstock expansion can provide useful insights into where expansion is most likely to occur. The absolute average annual expansion of areas harvested for key feedstocks in key regions is shown in Figure 6; some key trends are the expansion of soya production in South America, maize in Asia and the Americas, rape in Europe and oil palm in Asia. When we relate these trends to the distribution of suitable and available land (Figure 1), potential threats of adverse land use change can be observed, for example, cases where current expansion rates are unsustainable considering land availability. However, it is difficult to accurately anticipate how and where future biofuel feedstock expansion could drive deforestation and conversion of agricultural land without considering known historical processes and local realities. The following 3 subsections elaborate further on some of the most important ongoing expansion trends as they relate to land use competition, by examining some of the main biofuel feedstocks within the different regions.

\subsection{Oil palm expansion in Asia}

Indonesia and Malaysia account for approximately $46 \%$ and $41 \%$, respectively, of the total production of palm oil in 2008 (USDA FAS 2009b). During the period 2000-2008, oil palm was harvested on average from an additional 500000 ha of land every year, with Indonesia accounting for $65 \%$ and Malaysia $18 \%$ of this annual increase (based on FAOSTAT data, FAO 2010). In 2009, 7.9 million ha of land had been planted with oil palm in Indonesia from a total area of 9.7 million ha licenced to oil palm estates (Simamora 2010). In Malaysia, 4.69 million ha of land was planted with oil palm in 2009 (MPOB 2010). With more than $80 \%$ of Indonesia's and Malaysia’s palm oil 


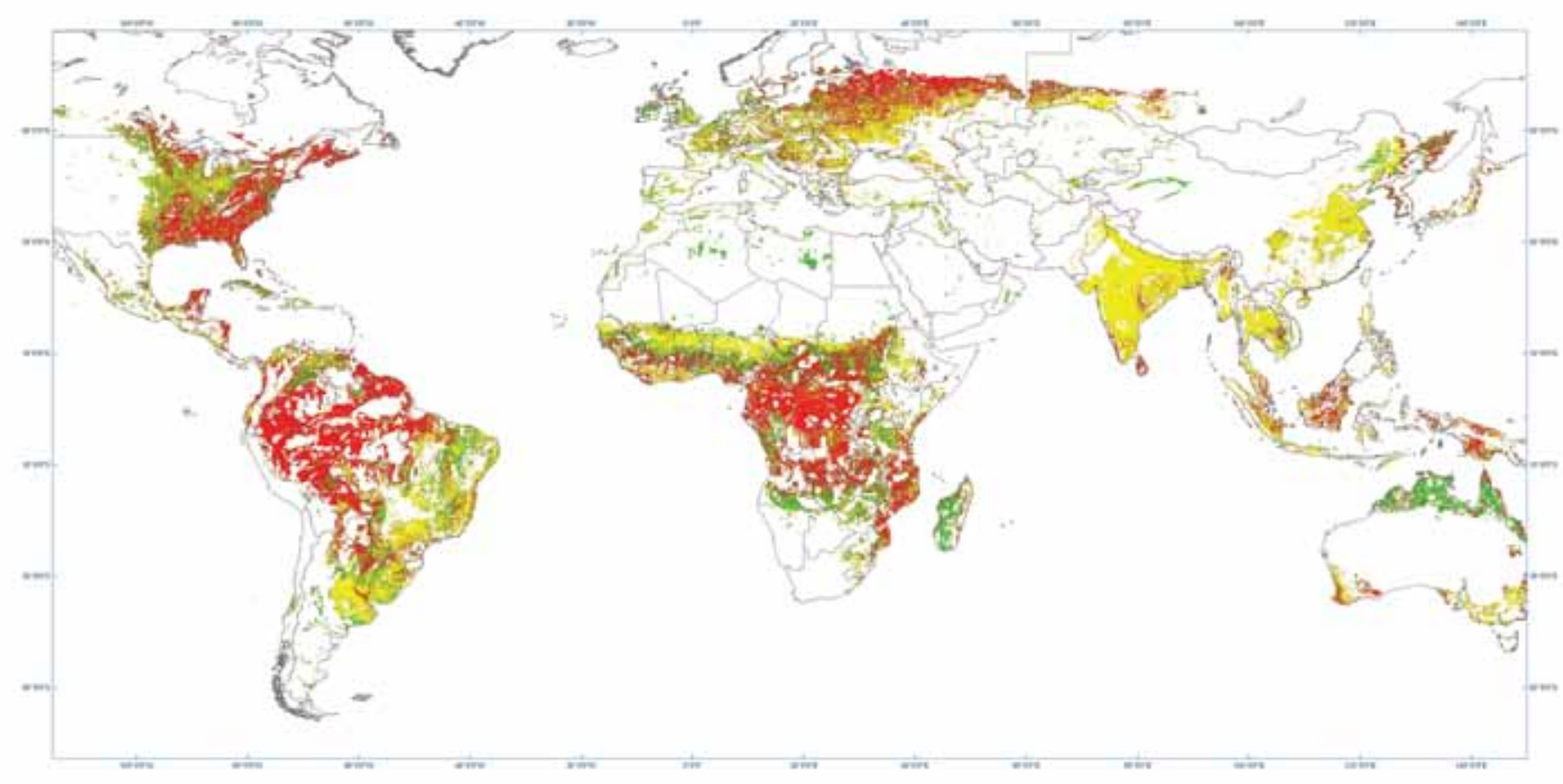

\section{Legend}

Unsuitable or otherwise unavailable

Suitable land under forest cover

Suitable land under agriculture

'Available'

\section{Figure 5. Competing land uses for suitable land worldwide}

Sources: Crop suitability (IIASA 2002); land cover (ESA 2006); protected area (WDPA 2009)

Notes:

- Biofuel feedstocks included are maize, rape, sunflower, soya, sugarcane, sugar beet and oil palm.

- Feedstocks were considered suitable for cultivation when moderate to very high yields are attainable (Suitability Index (SI) $>$ 25) under high inputs and under both rain-fed and irrigated conditions.

- Land considered 'otherwise unavailable' includes land with a protected status and artificial areas.

production typically exported on the global market, it is especially the growing global demand that is driving expansion. Emerging economies India and China have in recent years accounted for the bulk of this growth, collectively responsible for more than $60 \%$ of demand growth between 2005 and 2008 (calculated from USDA FAS 2009b). As the lowest-cost vegetable oil, palm oil is the most traded vegetable oil on the market, and thus also the most economically viable biodiesel feedstock. However, oil palm expansion is driven primarily by international demand for its food uses, which is estimated at $77 \%$ of total palm oil consumption (Sheil et al. 2009). According to Rupilius and Ahmad (2007), only 5\% of palm oil was transformed into biodiesel in 2007. The USDA FAS (2009a) reports similar figures for the EU, estimating that approximately $5 \%$ of biodiesel produced in the EU is derived from palm oil, which translates to roughly $6 \%$ of total EU palm oil imports (based on COMTRADE data, UN 2010). Despite its relatively limited application to date as a feedstock for biodiesel, global demand for biofuel feedstock in general will only serve to further stimulate demand for palm oil. For example, although Indonesia produced only about 91 million L of biodiesel in 2009, it currently has a production capacity of more than 4 million tons of biodiesel per year (van Gelder et al. in press), enough to service the entire projected EU import requirement of biodiesel by 2020 .

Whilst being an important source of foreign exchange earnings, the expansion of oil palm has 


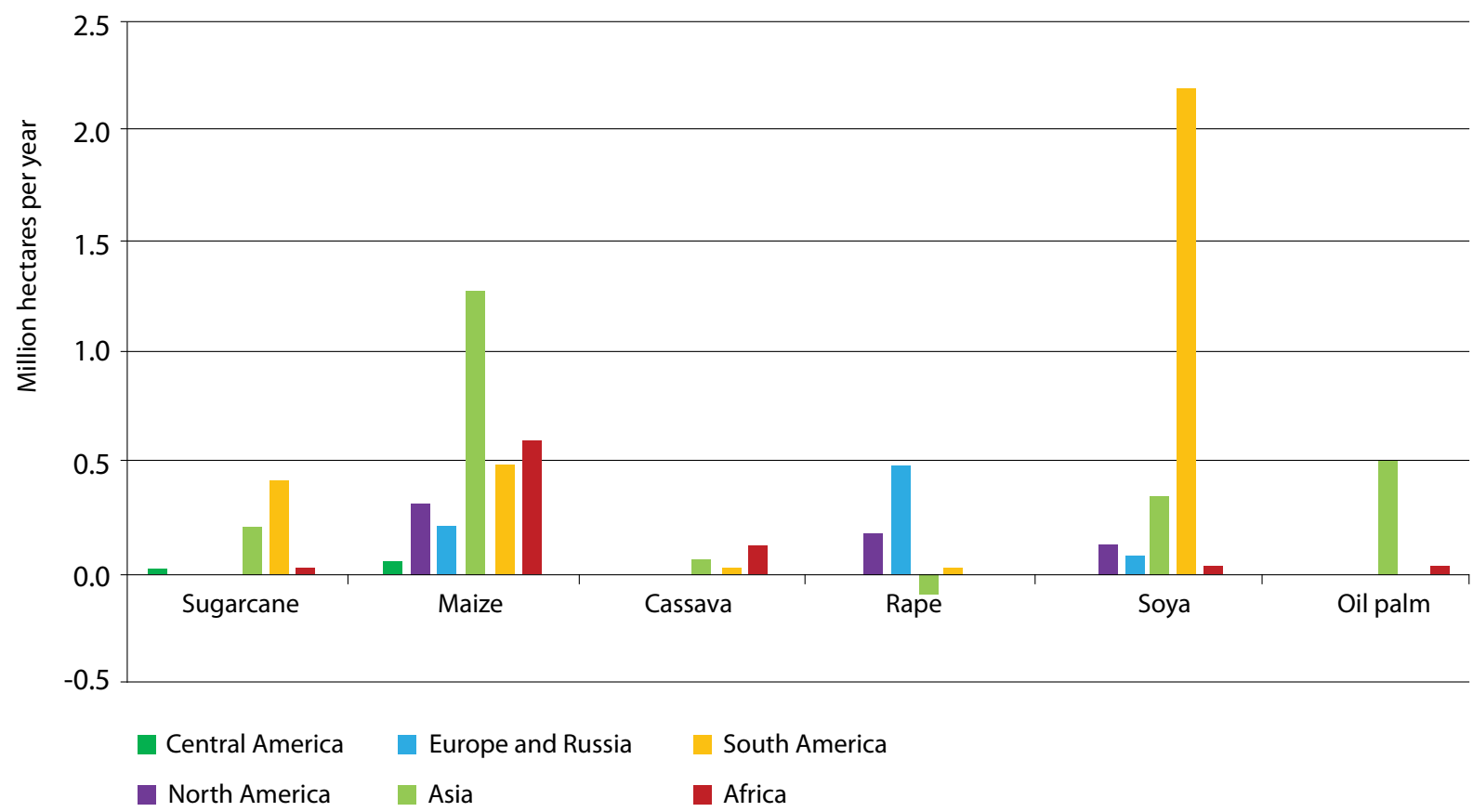

Figure 6. Average annual increase in area harvested of major feedstocks (2000-2008)

Source: Derived from FAO 2010

Note: Jatropha is not included as no official data on its cultivation are maintained.

become one of the leading drivers of deforestation in Southeast Asia in recent times. In Indonesia in particular, home to more than $75 \%$ of Southeast Asia's primary forests (FAO 2006), oil palm is decimating one of the most biologically diverse terrestrial ecosystems in the world. In terms of greenhouse gas emissions, Fargione et al. (2008) found the conversion of Indonesian rainforest to oil palm plantations to have some of the highest carbon $\mathrm{debt}^{6}$ of all types of land conversions for biofuel feedstock. By their calculations, it would take 423 years and 86 years to sequester the carbon emitted by the change of land use from peatland rainforest and tropical rainforest to oil palm, respectively.

Koh and Wilcove (2008) estimate that $55-59 \%$ and $56 \%$ of oil palm expansion between 1990 and 2005 occurred at the expense of forests in Malaysia and Indonesia, respectively. In the case of Indonesia, the Indonesian Ministry of Forestry (cited in Sheil et al. 2009) estimates this to be as high as $70 \%$ between 1982 and 1999. In Indonesia, however, it is assumed that much larger areas of forests have been cleared under the pretext of oil palm development without there ever having been any actual cultivation; this is because it is easier to obtain a licence to cultivate oil palm than to harvest timber (Casson 2003; Colchester et al. 2006). Furthermore, as oil palm only starts to bear fruit after approximately 3 years, oil palm producers are incentivised to specifically target forested areas to offset the cost of plantation establishment and the relatively long time to fully recover costs (Fitzherbert et al. 2008). In addition, the relatively high population densities in Indonesia's rural areas mean it is less cumbersome for oil palm companies seeking to acquire large contiguous areas of land to convert forestland, as land conflicts are then less likely to materialise. Nevertheless, most oil palm companies are in conflict with communities that hold customary claims to the land. Land acquired in the past has often been used by indigenous communities for swidden agriculture and for the harvesting of (nontimber) forest products; this is land to which rights are often insecure (Wakker 2005; Marti et al. 2008).

Expansion at the expense of forests will likely persist, particularly in Indonesia. For example, there are plans to convert 8.09 million ha to oil 
palm in Kalimantan (Indonesian Borneo) alone, of which 3.72 million ha is classified as forest (Venter et al. 2009). In 2006, Colchester et al. (2006) observed that across Indonesia local governments had plans to expand the area under oil palm by an additional 19.8 million ha. This target significantly exceeds the 5 million ha of land identified as being both suitable and potentially available for oil palm production in all of Asia (see Figure 1). Although oil palm expansion to date has certainly been the most intense and threatening in Indonesia and Malaysia, numerous other countries are starting to actively promote the oil palm sector. Of concern is that most recent expansions are taking place in forest-rich countries-notably in Republic of the Congo, Democratic Republic of the Congo, Cameroon, Brazil, Ecuador and Colombia. For example, in the Republic of the Congo, at least 3 European energy companies are developing large-scale oil palm plantations for the purpose of producing biodiesel. In the Democratic Republic of the Congo, a Chinese company has signed a Memorandum of Understanding for the development of up to 1 million ha of oil palm in the densely forested northern regions of the country (Mpoyi 2010), although only 100000 ha has actually been allocated to date (L. Putzel personal communication). Therefore, with increasing international recognition of oil palm's productivity and favourable prospects on export markets, there is a considerable risk, considering oil palm's suitability in forested areas, that its expansion could have dire environmental implications. A recent study, for instance, has shown that oil palm is often the most profitable land use of tropical forest, more so than other crops or carbon payment schemes (Butler et al. 2009).

\subsection{Soya expansion in South America}

Another important trend is the expansion of soya cultivation in South America. On average, an additional 2 million ha of land in South America, concentrated predominantly in south and centralwest Brazil and northern Argentina, is being brought into production every year (Figure 1). In 2008, Brazil and Argentina had 21.3 million and 16.4 million ha of land under soya cultivation, respectively-representing $38.8 \%$ of the total global area under soya cultivation and $46.0 \%$ of total global soya production quantity in that period (based on FAOSTAT data, FAO 2010). In recent years, other countries in the region, such as Paraguay, Bolivia and Uruguay, have also significantly increased their production capacity, although at significantly lower levels than those of Argentina and Brazil. The growth of the soya sector in South America is driven primarily by international demand. This is largely for soybean oil (for use in the food sector) and soybean meal (for use mainly as animal feed protein, having higher nutritional value than most other organic substitutes). The imports of soybean products by the EU and China represented more than $50 \%$ of the total global trade volume in 2008, with Brazil and Argentina accounting for $58 \%$ of the total global export volume of soybean products (based on USDA FAS 2009b; COMTRADE data, UN 2010) ${ }^{7,8}$ Whereas Brazil exports most of its soybean in unprocessed seed form, Argentina processes more than $80 \%$ of soybean seeds domestically into meal and oil, of which ultimately $97 \%$ and $76 \%$, respectively, are exported (ibid).

Although soybean oil is still primarily used for food purposes, Argentina and Brazil are increasingly using it as a feedstock for producing biodiesel. Currently, almost all biodiesel in both countries is derived from soybean oil. In Brazil, for example, the oil from approximately $16 \%$ of total soybean harvested is used for energy purposes-almost all used domestically (van Gelder et al. 2008). In Argentina, the oil from approximately $3.5 \%$ of total soybean harvested in 2008 was used to produce biodiesel-most of which, in contrast to Brazil, is exported (author's calculation based on data from van Gelder et al. 2008 and USDA FAS 2009a). Almost $15 \%$ of biodiesel produced in the EU in 2008 was derived from soybean oil, presumably about a third of which was imported from Argentina and Brazil (on the basis of the proportion of net imports to total consumption) (calculated from USDA FAS 2009a; 2009b).

Historically, soya has been grown in the tropical savannah areas of South America; however, technological advances and improved infrastructure have facilitated the advancement of soya cultivation into the Amazonian forest frontier, particularly in Brazil (Kaimowitz and Smith 2001; Nepstad et al. 2006). Morton et al. (2006) estimate that cropland 
expansion, mostly attributed to soya, contributed to $17 \%$ of total deforestation in the Brazilian state of Mato Grosso during the period 2001-2004. However, with the adoption of the Soy Moratorium in 2006, it is expected that the contribution of soya expansion to direct deforestation will be reduced significantly in Brazil. ${ }^{9}$

A simulation study conducted by Lapola et al. (2010) projects that for Brazil to meet its 2020 biodiesel consumption target, an additional 10.8 million ha of land would be required for soya cultivation. They expect that this expansion will lead to the direct conversion of 380000 ha of forest and the indirect conversion of 7 million ha of forest as a result of displaced cattle ranching. It is therefore the indirect, rather than direct, effect of soya expansion on deforestation that is considered most significant. It is argued that the expansion of agribusiness, particularly soya in Mato Grosso, will push cattle ranching-responsible for $70-80 \%$ of deforestation in the Amazon in Brazil-further into the forest frontier (Margulis 2004; Fearnside 2005; Piketty et al. 2005; Greenpeace-Brazil 2009). It is commonly held that cattle ranchers sell their land to soybean producers at a profit, as land prices rise due to the influx of soybean producers; the ranchers then reestablish in forested areas where land prices are lower (Nepstad et al. 2006; Fearnside 2008; Barona et al. 2010). As the economic returns from land for use as cattle ranching are significantly lower than those from soybean production, soya expansion tends to push cattle ranching into cheaper lands, which are often forested (Margulis 2004; Walker et al. 2009). Furthermore, the advancement of soya into the forest frontier stimulates infrastructure developments, which consequently further contribute to indirect deforestation as areas difficult and expensive to access become increasingly accessible to other economic agents (especially from the timber sector) (Anderson et al. 2002; Fearnside 2008).

On the basis of this thesis, it could be posited that the adoption of the Soy Moratorium could lead to greater displacement of pastureland as direct conversion of forested land to soya becomes less desirable. Thus the gains from avoided direct deforestation may be offset by the losses of increased indirect deforestation (through both displaced pastureland and infrastructure developments). However, although the interaction between soybean production and cattle ranching is well established amongst researchers, few have provided conclusive empirical evidence on the causal relationship. For example, one could argue that the expansion of cattle ranching into the Amazonian rainforest would have occurred to some extent even without the expansion of soybean production. As cattle ranchers are less likely to invest in soil rehabilitation (due to relatively low economic returns from land) (Pacheco 2005), pasture degradation and reduced stocking rates will further drive their pursuit of new land anyway.

\subsection{Jatropha expansion in Africa}

In Africa, rate of expansion of the area harvested of key biofuel feedstocks has been comparatively small in comparison to oil palm and soybean. However, Africa is endowed with some of the largest areas of land that are both suitable and available for further expansion (Figure 1). Despite the lack of a strong historical link between deforestation and expansion of biofuel feedstock, new opportunities presented by increasing global demand for biofuels could significantly increase pressure on agricultural and forested land. In recent years, foreign investors in particular have acquired sizeable areas of land around Africa for the explicit purpose of cultivating feedstocks through large-scale plantations. Whereas in South America and Asia most large-scale biofuel feedstock producers target predominantly the food and feed markets, with biofuels emerging as an opportunity for market diversification, in Africa most recent developments in biofuel feedstock production target exclusively the energy end-market. Although few of these developments have passed the inception stage, and many have reportedly become dormant as a result of the recent financial crisis and disappointing yields, their hypothetical expansion capacity (based on the areas of land to which they have access) is enormous. For example, since 2005, areas totalling more than 1.1 million ha have been accessed by commercial enterprises for feedstock cultivation in Ghana, 900 000 ha in Madagascar, approximately 640000 ha in Tanzania, 600000 ha in Zambia and 500000 ha in Mozambique (GTZ 2009; Sulle and Nelson 2009; Schoneveld et al. 2010; Schut et al. 2010; German et al. in press). 
The vast majority of these large-scale investments are concentrated on the cultivation of jatropha, with a smaller number of oil palm, sugarcane and cassava projects. In some countries, notably the West African countries of Senegal, Mali and Burkina Faso, jatropha is also being extensively grown by smallholders, typically through government- or donor-supported poverty alleviation and anti-desertification programmes. As this type of cultivation is often well integrated into existing farming systems, this rapid rise in large-scale jatropha monoculture is threatening to generate land use competition in many African countries. Although jatropha is often hailed for being able to grow under arid conditions, its productivity increases exponentially when cultivated on fertile soils, under moderate rainfall conditions and with more intense management (Achten et al. 2008; Neelakantan 2008; IFAD-FAO 2010). In practice, this implies that commercially oriented enterprises will often seek out lands with optimal conditions, which in turn increases the risks of land use competition as these lands are more likely to be more densely vegetated or part of the farming system. As can be observed from Figure 5, most of the aforementioned countries (bar Madagascar) have relatively high proportions of suitable land under competing uses. Considering especially that many of the proposed plantations cover more than 50000 ha of contiguous land, some degree of land use competition will be inevitable. Although conclusive evidence of adverse land use change is limited, anecdotal evidence suggests that many of these investments are displacing, or are threatening to displace, agricultural and forest land uses (see for examples Gordon-Maclean et al. 2009; Ribeiro and Matavel 2009; Schoneveld et al. 2010; Schut et al. 2010). As most customary land users in Africa have weak tenure rights, there is a substantial risk of involuntary loss of access to land and land-based livelihood resources (e.g. forest products and water) (Cotula et al. 2008). In Ghana, for example, households were required to relinquish landholdings for the purpose of plantation development at all of the 9 jatropha plantations assessed (Schoneveld et al. 2010). At most plantations, directly affected households were not consulted by the project developer, nor did they formally agree to transfer their land or receive any form of redress. The law in Ghana essentially allows traditional authorities to reallocate community land at their discretion, often without any formal downward accountability to community members, who enjoy no formal rights to the land they use. Similar processes have been observed in Zambia. For instance, one company obtained more than 400000 ha of customary land (used predominantly for charcoal burning and swidden agriculture) from 4 chiefdoms, without there being any specific restitution for directly affected households (German et al. in press). Gordon-Maclean et al. (2009) report that, in Tanzania, 5 out of the 7 recent biofuel feedstock plantations assessed in their research comprise forested land of high conservation value. Thus, although sufficient land is in theory 'available' across Africa, in practice those lands that are targeted for plantation agriculture will tend to have various conflicting ex ante land uses. As long as administrative land allocations continue to be based on opaque transactions, the long-term future of biofuel plantations will be marked by conflicts with neighbouring agriculture- and forestdependent communities.

\subsection{Land requirements for biofuel blending in developing countries}

In highlighting some of the potential threats, the above discussion has painted a relatively bleak picture of the potential land use implications of biofuel feedstock expansion. Historically, as illustrated by the above examples of soya expansion in South America and oil palm expansion in Southeast Asia, the food and feed sectors have predominantly been the key driving forces behind expansions. With the exception of a small, albeit increasing, number of cases, it would be inaccurate to ascribe these trends to the biofuel sector per se. Therefore, it is relevant at this point to assess the potential future demand on land should developing countries seek to implement mandatory blending regulations and/or pursue biofuel feedstock production from a trade perspective.

This section calculates the extent of land that would be required in a situation where developing countries impose the mandatory blending of first-generation biofuels. The amounts of key domestically produced biodiesel feedstock that would be required in selected countries should biodiesel substitute for $10 \%$ of petrodiesel 
Table 3. Scenarios for $10 \%$ petrodiesel substitution with biodiesel in the transportation sector for selected countries

\begin{tabular}{lccc}
\hline Country & $\begin{array}{l}\text { Additional } \\
\text { biodiesel required } \\
\text { (million L) }\end{array}$ & $\begin{array}{l}\text { Proportion of total } \\
\text { feedstock harvest required } \\
\text { to meet biodiesel target } \\
\text { (\%) }\end{array}$ & $\begin{array}{c}\text { Area required } \\
\text { (ha) for dedicated } \\
\text { plantations }\end{array}$ \\
\hline Biodiesel derived from oil palm & 592.7 & 3.7 & 148092 \\
\hline Malaysia* & 1097.9 & 6.4 & 269722 \\
\hline Indonesia* & 37.0 & 13.2 & 9238 \\
\hline Cameroon & 108.8 & 6.4 & 27196 \\
\hline Nigeria & 37.0 & 15.4 & 9238 \\
\hline Côte d'Ivoire & 389.6 & 60.9 & 97402 \\
\hline Colombia* & 284.7 & 67.8 & 71182 \\
\hline Ecuador & & & 237715 \\
\hline Biodiesel derived from soybean & 106.7 & 8.6 & 190452 \\
\hline Paraguay* & 85.7 & 29.8 & 1926360 \\
\hline Bolivia & 868.6 & 10.4 & 65117 \\
\hline Argentina* & 29.3 & 155.0 & 17654221 \\
\hline Zimbabwe & 7944.4 & 284.0 & 7491610 \\
\hline China* & 3360.2 & 207.0 & \\
\hline India* & & & \\
\hline
\end{tabular}

Source: Derived from EIA (2010), FAO (2010), IEA (2010)

a. Biodiesel requirement calculated from IEA (2010) data on petrodiesel consumption in the transportation sector for the year 2007. Differences in densities and calorific values are considered in the calculation. The volume of biodiesel already consumed in relevant countries has been accounted for using EIA (2010) data for the year 2008, assuming that all biodiesel consumed is used by the transportation sector. These countries are marked with an asterisk $(*)$.

b. Unprocessed harvest figures are from FAO (2010). The calculation assumes oil palm has an oil extraction rate of $20 \%$ and soybean an oil extraction rate of $18 \%$.

c. Area required assumes that 1 ha will on average yield $4000 \mathrm{~L}$ of biodiesel from oil palm and $450 \mathrm{~L}$ from soybean. However, yields can vary between operators and countries, depending on level of management and agronomic conditions, amongst other factors.

Note: Countries selected have a relatively well-developed domestic feedstock sector and a low level of biodiesel in their energy mix.

consumed by the transportation sector are shown in Table 3. It can be observed that, especially for palm oil-producing countries, present production capacity is sufficient to meet such blending targets. However, in many countries, the diversion of feedstock to the domestic production of biofuels would lead to domestic shortages of feedstock for use as food. Consequently, feedstock would in many cases need to be imported again, thereby potentially offsetting any gains from blending to the trade balance, and potentially driving up domestic feedstock prices. This would certainly be the case for many producer countries; the exceptions are Malaysia, Indonesia, Paraguay, Bolivia and Argentina, as in these countries the domestic production surplus (based on net export volume) is larger than the potential feedstock demand in a 10\% biodiesel-blending scenario. Moreover, for some countries, feedstock cultivation is an important foreign exchange earner. Thus, to prevent conflict with other end-uses and markets, an increase in the importation of feedstock (products) and/or a loss in 
Table 4. Scenarios for $10 \%$ gasoline substitution with ethanol in the transportation sector for selected countries

\begin{tabular}{|c|c|c|c|c|c|}
\hline Country & $\begin{array}{l}\text { Additional } \\
\text { ethanol } \\
\text { required } \\
\text { (million L) }\end{array}$ & $\begin{array}{l}\text { Proportion } \\
\text { of harvest to } \\
\text { meet ethanol } \\
\text { target - cane } \\
\text { juice route } \\
\quad(\%)\end{array}$ & $\begin{array}{l}\text { Proportion of } \\
\text { harvest to meet } \\
\text { ethanol target } \\
\text { - A-molasses } \\
\text { route }^{\mathrm{a}} \\
\quad(\%)\end{array}$ & $\begin{array}{l}\text { Proportion of } \\
\text { harvest to meet } \\
\text { ethanol target } \\
\text { - C-molasses } \\
\text { route }^{\text {a }} \\
\quad(\%)\end{array}$ & $\begin{array}{l}\text { Area required } \\
\text { (ha) for } \\
\text { dedicated } \\
\text { plantations }^{\text {b }}\end{array}$ \\
\hline Argentina & 731.6 & 36.6 & 105.5 & 304.8 & 164317 \\
\hline Guatemala & 159.6 & 9.4 & 27.1 & 78.3 & 35834 \\
\hline Peru & 151.6 & 24.6 & 70.8 & 204.7 & 30315 \\
\hline Philippines* & 476.2 & 26.9 & 77.3 & 223.2 & 107062 \\
\hline Thailand* & 783.2 & 14.2 & 50.6 & 118.4 & 156639 \\
\hline Vietnam & 544.8 & 50.6 & 145.9 & 421.5 & 122355 \\
\hline Mozambique & 18.1 & 11.0 & 31.8 & 92.0 & 4058 \\
\hline Tanzania & 41.4 & 26.1 & 75.4 & 217.8 & 9293 \\
\hline Zambia & 30.7 & 18.4 & 53.1 & 153.3 & 6899 \\
\hline
\end{tabular}

Source: Author, derived from EIA 2010, FAO 2010, IEA 2010

a. These calculations are made using sugarcane harvesting data from FAO $(2010)$ and assuming that 75,26 and $9 \mathrm{~L}$ can be produced per ton of sugarcane via the cane juice, A-molasses and C-molasses production routes, respectively.

b. Area required assumes that $5000 \mathrm{~L}$ of ethanol can be produced per ha under sugarcane cultivation.

Note: Countries selected have a relatively well-developed domestic sugarcane sector and a low level of ethanol in their energy mix.

foreign exchange earnings would be inevitable in every country, in a situation where yields remain constant. Therefore, an expansion in the area harvested would likely be the preferred course of action for most countries. The far-right column in Table 3 shows the additional amount of land required should diversion of currently produced feedstock to biofuels be avoided. As is evident, in most developing countries, a single large oil palm plantation could meet all of the domestic biodiesel demand. However, significantly larger areas of land would be required for soya due to its relatively low oil yield per ha (approximately 450 L, compared with more than $4000 \mathrm{~L}$ for oil palm).

In the case of ethanol produced from sugarcane, this conflict between end-uses and the effects on the trade balance may not be as intense. Although ethanol can be produced directly from the cane juice obtained from the first crushing, it can also be produced from molasses, a by-product from sugar production. The final molasses (called C- or blackstrap molasses) typically has limited economic value and is often used as cattle feed supplement or a flavouring agent, or is sometimes disposed off (Gopal and Kammen 2009). Since these molasses can be used to generate much greater economic gains by making ethanol, many sugar producers are starting to develop integrated sugar and ethanol factories. The proportions of sugarcane required via the different production routes to produce ethanol in key sugarcaneproducing countries are shown in Table 4. As can be observed, 2 of these countries could produce the necessary ethanol from existing $\mathrm{C}$-molasses without it strongly conflicting with other endmarkets (e.g. food and feed sectors). Should higher-quality molasses be used (from which sugar is still salvageable), most countries would be able to meet their ethanol requirements, although this would somewhat reduce the quantity of sugar produced. Even in situations where existing sugar producers do not diversify into ethanol production, the ethanol needs of most developing countries can, as with oil palm, be met by a single medium to large plantation. 


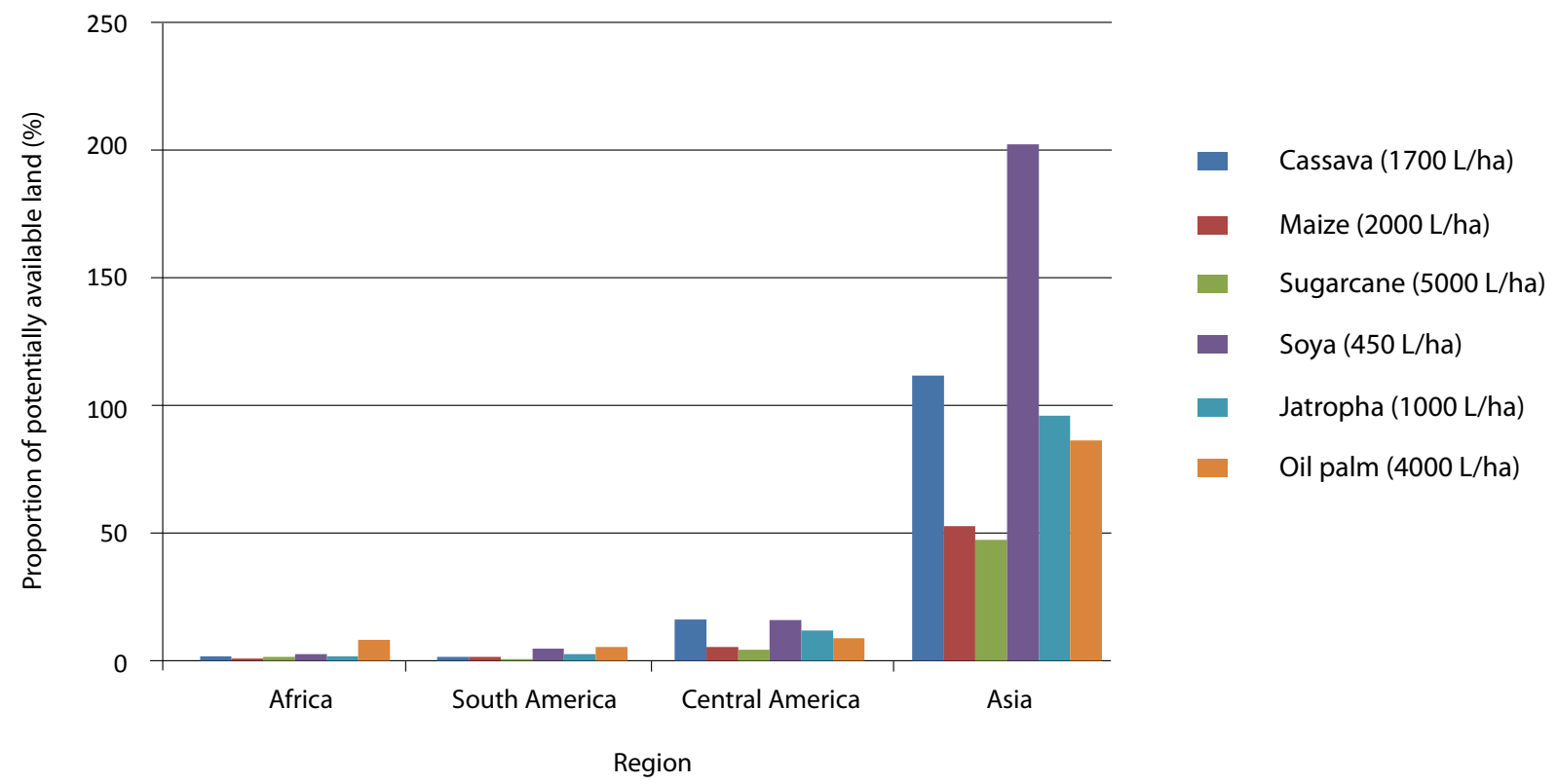

Figures 7. Percentage of suitable land not classified as forest or cultivated land (for selected feedstocks) required to substitute biodiesel and ethanol produced from key feedstocks for $10 \%$ of petroleum consumption in the transportation sector

Source: Derived from EIA 2010, FAO 2010, Fischer et al. 2009, IEA 2010

a. Since Brazil has higher blending mandates than used in these scenarios, Brazil is excluded from the South America ethanol figures.

b. Biofuel requirements are calculated from IEA (2010) data on oil consumption in the transportation sector and account for differences in densities and calorific values for each type of biofuel. The volume of biofuel already consumed in relevant countries has been accounted for using EIA (2010) data, assuming that all biofuel consumed is used by the transportation sector. Land suitability data are taken from Fischer et al. 2009.

Using regional data, calculations were made to determine the proportion of suitable and potentially available land that would be required to substitute $10 \%$ of petrodiesel and gasoline consumption in the transportation sector with biodiesel and ethanol produced from key feedstocks (Figures 7). From this it is apparent that in Africa, Central America and South America, sufficient suitable and available land is available for the cultivation of the feedstocks assessed. For most feedstocks, less than $10 \%$ of the suitable and available land would be required to meet domestic uptake targets. In Asia, on the other hand, large proportions of suitable and available land would be required and, in the case of soya and cassava, for example, more than is available (under a scenario where one feedstock is used). Since this analysis does not consider the projected long-term demand for fossil fuels, the required area under cultivation would need to increase by the rate of growth of oil demand (with all other assumptions remaining constant). Whilst this typically varies greatly between countries, regional estimates of long-term annual growth are $1.2 \%, 1.2 \%$ and $2.8 \%$ for Africa, Central and South America and Asia, respectively (EIA 2009).

This analysis shows that in Asia the extensive incorporation of biofuels into the energy mix may not be suitable from a sustainable land use perspective; however, it also illustrates that in the other regions assessed, biofuel feedstock expansion need not necessarily lead to adverse land use competition. This implies that it could hypothetically be extremely feasible to have biofuel feedstock cultivated on genuinely available lands for the purpose of biofuels under the right combination of regulations and incentives. Furthermore, this also implies that all 3 regions have more than sufficient suitable resources available to produce additional biofuels for the main projected import markets of the EU and USA. For example, drawing on the figures from OECD-FAO (2010), their combined external demand by 2019 would require that, globally, approximately 2 million ha of 
biodiesel feedstock and 4.5 million ha of ethanol feedstock be brought under cultivation to service these markets. ${ }^{10}$ Considering that for soya, jatropha, sugarcane and oil palm, approximately 680 , 570, 220 and 44 million ha of land, respectively, are considered to be potentially available and suitable around the world (almost all of which is in developing countries), medium-term demand from net biofuel-importing industrialised nations does not necessarily need to have strongly negative effects on sustainable land use. Especially in the EU, where, through the Renewable Energy Directive adopted in 2009, the nature and net carbon effect of land use change for the cultivation of biofuel feedstock need to be accounted for, the risk that their external demand contributes to deforestation in developing countries is considerably reduced. Thus, although international shifts in demand for biofuels will certainly contribute to land use change, as new economic opportunities are sought, other sectoral drivers, such as demand from large emerging markets for vegetable oils for food, for instance, may have a considerably more detrimental impact on land. For example, FAPRI (2010) projects that the net external demand for soybean and palm oil in China and India alone will grow by more than 7 billion L between 2009 and 2019-predominantly due to growing use in food products, driven by increasing per capita spending power. This is almost double the volume of biodiesel the EU and USA will need to import by 2019 .

\section{Conclusion}

This analysis has shown that sufficient suitable land is theoretically available in developing countries for the cultivation of biofuel feedstock. Many developing countries, especially in South America and Africa, have the potential to use locally produced biofuels for blending on the domestic market, whilst also servicing international demand. Not only would this increase domestic energy security, but it would also contribute to economic development by capitalising on emerging trade and investment opportunities. Despite this potential, the high proportion of suitable land that is not considered to be available raises concerns about adverse land use change impacts-in particular considering that historically (e.g. for oil palm and soya) this has already proven to be the case. In the absence of national incentives and regulations to minimise land use competition, biofuel expansion could exacerbate food insecurity, rural poverty and deforestation rates.

Since many developing countries are still to develop dedicated biofuel policies or lack the capacity to effectively regulate large-scale land-based investments, the private sector may target lands predominantly from the perspective of generating the highest return on investment. These lands are likely to have the greatest agronomic potential, but also are most likely already to be, for those same reasons, under cultivation or of high ecological significance (especially in the case of oil palm and sugarcane). Thus, in many countries, particularly where biofuel expansion is currently taking place in a regulatory vacuum, mechanisms need to be developed to regulate the many facets of biofuels.

Foremost, there is a need for mechanisms to ensure that proposed projects take place on land that is genuinely available. As discussed in this paper, land that may be considered to be potentially 'available' may provide important ecological services or be integral to livelihood systems. This concern raises important methodological questions regarding how to effectively assess land availability. Rather than relying exclusively on remote-sensing analysis, onthe-ground assessments are necessary to capture the unique social, economic and environmental functions of different landscapes, going beyond the overly simplified land use classifications often adopted. This entails needs such as the capacities of certified consultancies to conduct, and governments to evaluate, environmental impact assessments often required for large-scale biofuel developments. It should also entail a strongly participative and consultative impact identification process, which engages all stakeholder groups, particularly those that are often sidelined in these community participation initiatives, such as women, pastoralists and ethnic minority groups. In so doing, due recognition should be given to complex systems of (informal and overlapping) local resource rights to ensure these are effectively protected in the context of large-scale land use change. Detailed methodological guidelines could serve as important reference material to developing procedures that are appropriate and 
effective within given contexts. Furthermore, it is critical that social, economic and environmental safeguards are imposed to regulate the activities of project developers and protect the rights of land users; such safeguards could be driven not only by national legislation, but also by market forces such as voluntary certification systems and mandatory systems of standards such as those adopted by the EU. Of particular importance is the need to reduce the opacity and elite capture of land transactions and enhance the security of customary land rights, particularly in sub-Saharan Africa. At the very least, the adherence to the principle of free, prior and informed consent would serve to contribute to more Pareto-optimal outcomes, promulgated for instance through land laws or incorporated into (international) sustainability initiatives.

Detailed and comprehensive land suitability and availability assessments should also be considered prior to formalising sector objectives and supporting policies; for instance, where capacity exists, this could occur as part of Strategic Environmental Assessments. Furthermore, a sector-specific land use planning or agro-ecological zoning exercise would help in identifying where and how much land could potentially be available for biofuel expansion without creating undue land use competition. This in turn would contribute to defining policy objectives and support the identification of specific feedstocks to create minimal land use competition. For instance, it would provide valuable insights into whether and to what extent trade and investment opportunities should be embraced. In most situations where suitable and available lands are relatively scarce, an inwardly focused, energy security agenda would often be most appropriate, considering the implications of high external dependency on imported fossil fuels. 


\section{Endnotes}

1 This is based on conversion factors adopted from USDA FAS (2009a): 1000 litres of ethanol $=0.507$ toe; 1000 litres of biodiesel $=0.788$ toe.

2 Neither report explains how imported feedstock (e.g. vegetable oils) is accounted for in the projections; thus, it remains unclear whether figures on imported biofuels include imported feedstock that is processed within the EU or USA.

3 The OECD includes most of the European Union, North America, Japan, New Zealand, Australia, South Korea and Turkey.

4 The 'agro-ecological zones methodology' used by IIASA/FAO, for example, uses a standardised framework for the characterisation of 'climate, soil and terrain conditions' relevant to agricultural production. Crop modelling and environmental matching procedures are used to identify cropspecific limitations of prevailing climate, soil and terrain resources, under assumed levels of inputs and management conditions.

5 Lands classified as forests in this analysis are areas spanning more than 0.5 ha with trees taller than 5 metres and a canopy cover more than $10 \%$. Sparse woodlands are areas where canopy cover ranges from $5 \%$ to $10 \%$. Land classified as cultivated is land under rain-fed and irrigated crop production.
6 Carbon debt is the time taken to sequester or mitigate the amount of greenhouse gas emitted from land conversion (e.g. through burning, decomposition or release of soil carbon).

7 In 2001, the EU imposed a ban on the use of animal-based proteins for feeding livestock. The feed shortage this created was met primarily by soybean-based animal feed (Nepstad et al. 2006). 8 The volume of soybean products is derived by aggregating the volume of soybean seeds, soybean meal and soybean oil. These represent, respectively, $57.6 \%, 37.9 \%$ and $6.5 \%$ of the total global trade volume in 2008.

9 The private sector associations ABIOVE and ANEC (whose members are responsible for approximately $90 \%$ of the trade volume) and civil society agreed to cease the trade of soybeans produced on land deforested after 24 July 2006 within the Amazon Biome of Brazil (Lovatelli and Adario 2009).

10 This assumes that to produce each biofuel type a combination of feedstocks will be used, yielding approximately $2000 \mathrm{~L}$ per ha for biodiesel and 3000 $\mathrm{L}$ per ha for ethanol. The US and EU combined net import of biodiesel is projected at 3.9 billion litres and of ethanol at 14.1 billion litres (OECDFAO 2010). 


\section{References}

Achten, W.M.J., Verchot, L., Franken, Y.J., Mathijs, E., Singh, V.P., Aerts, R. and Muys, B. 2008 Jatropha biodiesel production and use. Biomass Bioenergy 32(12): 1063-1084.

Aksoy, M.A. and Isik-Dikmelik, A. 2008 Are low food prices pro-poor? Net food buyers and sellers in low-income countries. World Bank, Washington, DC.

Anderson, L.E.C., Granger, W.J., Reis, E.J., Weinhold, D. and Wunder, S. 2002 The dynamics of deforestation and economic growth in the Brazilian Amazon. Cambridge University Press, Cambridge, UK.

Anonymous 2008 Agrofuels and the myth of the marginal lands. The Gaia Foundation, Biofuelwatch, the African Biodiversity Network, Salva La Selva, Watch Indonesia and EcoNexus, London and Oxford, UK. 8p.

Barona, E., Ramankutty, N., Hyman, G. and Coomes, O.T. 2010 The role of pasture and soybean in deforestation of the Brazilian Amazon. Environmental Research Letters 5: 024002 doi: 10.1088/1748-9326/5/2/024002.

British Petroleum (BP) 2009 BP statistical review of world energy. BP, London.

Butler, R.A., Koh, L.P. and Ghazoul, J. 2009 REDD in the red: palm oil could undermine carbon payment schemes. Conservation Letters 2 : 67-73.

Casson. A. 2003 Oil palm, soybeans and critical habitat loss. WWF Forest Conservation Initiative, Hohlstrasse, Switzerland.
Colchester, M., Jiwan, N., Sirait, S.M., Firdaus, A.Y., Surambo, A. and Pane, H. 2006 Promised land: palm oil and land acquisition in Indonesia - implications for local communities and indigenous peoples. Forest Peoples Programme, Perkumpulan Sawit Watch, HuMA and the World Agroforestry Centre, Moreton-inMarsh, UK.

Cotula, L., Dyer, N. and Vermeulen, S. 2008 Fuel exclusion? The biofuel boom and the poor's access to land. International Institute for Environment and Development, London.

Deininger, K. 2003 Land policies for growth and poverty reduction. World Bank Research Policy Report. World Bank, Washington, DC.

Department for Environment, Food and Rural Affairs (DEFRA) 2010 The 2007/2008 agricultural price spikes: causes and consequences. DEFRA, London.

Energy Information Administration (EIA) 2009 World energy outlook 2009. US Department of Energy, Washington, DC.

Energy Information Administration (EIA) US energy information administration database of international energy statistics. http://www.eia. doe.gov/international [8 March 2010].

European Space Agency (ESA) 2006 Globcover: Global Land Cover Project. ESA.

Food and Agriculture Organization of the United Nations (FAO) 2006 Global forest resource assessment 2005: progress towards sustainable forest management. FAO, Rome. 
Food and Agriculture Organization of the United Nations (FAO) 2009 The state of agricultural commodity markets: high food prices and the food crisis - experiences and lessons learned. FAO, Rome.

Food and Agriculture Organization of the United Nations (FAO) FAOSTAT: agricultural production data. http://faostat.fao.org/site/567/ default.aspx\#ancor [10 September 2010].

Food and Agriculture Organization of the United Nations (FAO) and Global BioEnergy Partnership (GBEP) 2007 A review of the current state of bioenergy development in G8 +5 countries. FAO, GBEP, Rome.

Food and Agriculture Organization of the United Nations (FAO), International Fund for Agricultural Development (IFAD) and World Food Programme of the United Nations (WFP) 2008 High food prices: impacts and recommendations for actions. Paper prepared for meeting of the Chief Executive Board for Coordination. Bern, Switzerland, 28-29 April.

Food and Agriculture Policy Research Institute (FAPRI) 2010 US and world agricultural outlook. FAPRI, Ames, Iowa, USA.

Fargione, J., Hill, J., Tilman, D., Polasky, S. and Hawthorn, P. 2008 Land clearing and the biofuel carbon debt. Science 319: 1235-1238.

Fearnside, P.M. 2005 Deforestation in Brazilian Amazonia: history, rates, and consequences. Conservation Biology 19(3): 680-688.

Fearnside, P.M. 2008 The roles and movements of actors in the deforestation of Brazilian Amazonia. Ecology and Society 13(1): 34 [online] URL: http://www.ecologyandsociety. org/vol13/iss1/art23/.

Fischer, G., Hizsnyik, E., Prieler, S., Shah, M. and van Velthuizen, H. 2009 Biofuels and food security: implications of an accelerated biofuels production. Summary of the OFID prepared by International Institute for Applied Systems Analysis (IIASA). OFID Pamphlet Series. The OPEC Fund for International Development, Vienna, Austria.

Fitzherbert, E.B., Struebig, M.J., Morel, A., Danielsen, F., Brühl, C.A., Donald, P.F. and Phalan, B. 2008 How will oil palm expansion affect biodiversity? Trends in Ecology and Evolution 23: 538-545.

German, L., Schoneveld, G.C. and Gumbo, D. In press. The potential impact of bioenergy development in Zambia. CIFOR, Bogor, Indonesia.

Gesellschaft für Technische Zusammenarbeit (GTZ) 2009 Foreign direct investment in land in Madagascar. Division 45 - Agriculture, fisheries and food, GTZ, Eschborn.

Gopal, A.R. and Kammen, D.M. 2009 Molasses for ethanol: the economic and environmental impacts of a new pathway for the lifecycle greenhouse gas analysis of sugarcane ethanol. Environmental Research Letters 4: 044005. doi: 10.1088/1748-9326/4/4/044005.

Gordon-Maclean, A., Laizer, J., Harrison, P. and Shemdoe, R. 2009 Biofuel industry study, Tanzania: an assessment of the current situation. World Wide Fund for Nature Tanzania, Dar es Salaam, Tanzania. 94p.

Greenpeace-Brazil 2009 Amazon cattle footprint. Greenpeace-Brazil, Sao Paolo, Brazil.

International Energy Agency (IEA) International energy statistics. Statistical database. http:// www.iea.org/stats/index.asp [8 March 2010].

International Fund for Agricultural Development (IFAD) and Food and Agriculture Organization of the United Nations (FAO) 2010 Jatropha: a smallholder energy crop - the potential for propoor growth. FAO, Rome.

International Institute for Applied Systems Analysis (IIASA) 2002 Global agro-ecological assessment in the 21st century. IIASA, Vienna, Austria.

IUCN and UNEP 2009 The world database on protected areas (WDPA). UNEP-WCMC. Cambridge, UK.

Kaimowitz, D. and Smith, J. 2001 Soybean technology and the loss of natural vegetation in Brazil and Bolivia. In: Angelsen, A. and Kaimowitz, D. (eds.) Agricultural technologies and tropical deforestation, 195-212. CIFOR and CABI Publishing, New York.

Koh, L.P. and Wilcove, D.S. 2008 Is oil palm agriculture really destroying tropical biodiversity? Conservation Letters 1(2): 60-64.

Kojima, M. and Johnson, T. 2005 Potential for biofuels for transport in developing countries. 
Energy Sector Management Assistance Program, World Bank, Washington, DC.

Lapola, D.M., Schaldacha, R., Alcamoa, J., Bondeau, A., Koch, J., Koelking, C. and Priess, J.A. 2010 Indirect land-use changes can overcome carbon savings from biofuels in Brazil. Proceedings of the National Academy of Sciences 107: 3388-3393.

Lovatelli, C. and Adario, P. 2009 Soy moratorium - third anniversary. Presented at GTS. Brasilia, Brazil, 18 July.

Malaysian Palm Oil Board (MPOB) 2010 Overview of the Malaysian palm oil industry 2009. MPOB, Kuala Lumpur, Malaysia.

Margulis, S. 2004 Causes of deforestation of the Brazilian Amazon. World Bank Working Paper No. 22. World Bank, Washington. D.C.

Marti, S., Tarigan, A. and Griffiths, H. 2008 Losing ground: the human rights impacts of oil palm plantation expansion in Indonesia. Friends of the Earth, London.

Morton, D.C., DeFries, R.S., Shimabukuro, Y.E., Anderson, L.O., Arai, E., del Bon Espirito-Santo, F., Frietas, R. and Morisette, J. 2006 Cropland expansion changes deforestation dynamics in the southern Brazilian Amazon. Proceedings of the National Academy of Sciences 103: 14637-14641.

Mpoyi, A. 2010 Les dimensions sociales et environnementales de projets d'acquisition a grande echelle des de droits fonciers en Republique Democratique du Congo. Paper presented at the World Bank Annual Conference on Land Policy and Administration. Washington, DC, 26-27 April.

Neelakantan, K.S. 2008 Jatropha curcas. Forest College and Research Institute, Tamil Nadu Agricultural University, Mettupalayam, India.

Nepstad D., Stickler, C. and Almeida, O. 2006 Globalization of the Amazon soy and beef industries: opportunities for conservation. Conservation Biology 20: 1595-1603.

Organisation for Economic Co-operation and Development (OECD) and Food and Agriculture Organization of the United Nations (FAO) 2010 OECD-FAO agricultural outlook 2010-2019. OECD, Paris.

Pacheco, P. 2005 Populist and capitalist frontiers in the Amazon: diverging dynamics of agrarian and land-use change. Ph.D. Thesis. Graduate School of Geography, Clark University, Massachusetts, USA.

Peters, J. and Thielmann, S. 2008 Promoting biofuels: implications for developing countries. Ruhr Economic Papers, 38. Ruhr-Universitat Bochum, Bochum, Germany. 18p.

Piketty M.G., Bastos da Veiga J., Tourrand J.F., Negreiros Alves A.M., Poccar-Chapuis, R. and Thales, M. 2005 Les déterminants de l'expansion de lélevage bovin en Amazonie orientale: conséquences pour les politiques publiques. Cahier Agricultures 14(1): 90-95.

Rajagopal, D. and Zilberman, D. 2007 Review of environmental, economic, and policy aspects of biofuels. Policy Research Working Paper No. 4341. World Bank, Washington, DC.

Renewable Energy Policy Network for the 21st Century (REN21) 2009 Renewables global status report: 2009 update. REN21 Secretariat, Paris.

Ribeiro, D. and Matavel, N. 2009 Jatropha! A socio-economic pitfall for Mozambique. Justiça Ambiental and União Nacional de Camponeses, (Maputo), Mozambique. 51p.

Rossi, A. and Lambrou, Y. 2008 Gender and equity issues in liquid biofuels production: minimizing the risks and maximizing the opportunities. Food and Agriculture Organization of the United Nations, Rome.

Rupilius, W. and Ahmad, S. 2007 Palm oil and palm kernel oil as raw materials for basic oleochemicals and biodiesel. European Journal of Lipid Science and Technology 109: 433-439.

Schoneveld, G.C., German, L.A. and Nukator, E. 2010 Towards sustainable biofuel development: assessing the effectiveness of the Ghanaian legal and institutional framework. Paper prepared for World Bank Annual Conference on Land Policy and Administration. Washington, DC, 26-27 April.

Schut, M., Bos, S., Machuama, L. and Slingerland, M. 2010 Working towards sustainability: learning experiences for sustainable biofuel strategies in Mozambique. Wageningen University, Wageningen, Netherlands.

Sheil, D., Casson, A., Meijaard, E., van Noordwijk, M., Gaskell, J., Sunderland-Groves, J., Wertz, K. and Kanninen, M. 2009 The impacts and opportunities of oil palm in southeast Asia: what 
do we know and what do we need to know? Occasional Paper 51. CIFOR, Bogor, Indonesia.

Simamora, A.P. 2010 Govt drops designating plantations as forests. The Jakarta Post, 4 April.

Sugrue, A. 2008 Bioenergy production on marginal and degraded land: the potential social impacts. Paper prepared for the Joint International Workshop on High Nature Value Criteria and Potential for Sustainable Use of Degraded Lands. Paris, 30 June-1 July.

Sulle, E. and Nelson, F. 2009 Biofuels, land access and rural livelihoods in Tanzania. International Institute for Environment and Development, London.

UN COMTRADE commodity trade statistics database http://comtrade.un.org/ [20 April 2010].

United States Department of Agriculture Foreign Agriculture Services (USDA FAS) 2009a EU-27 biofuels annual report. USDA FAS, The Hague, Netherlands.

United States Department of Agriculture Foreign Agriculture Services (USDA FAS) 2009b Oil seeds: world market and trade, Circular Series FOP 12-09. USDA FAS, Washington, DC.

van Gelder, J.W., Bailis, R. and German, L. In press. Global and regional trends and scenarios in bioenergy trade and investment: an analysis of forest-rich countries in Asia, Latin America, and Africa. CIFOR, Bogor, Indonesia.

van Gelder, J.W., Kammeraat, K. and Kroes, H. 2008 Soy consumption for feed and fuel in the European Union. A research paper prepared for Milieudefensie (Friends of the Earth Netherlands). Profundo, Castricum, Netherlands. 22p.

Venter, O., Meijaard, E., Possingham, H.P., Dennis, R., Sheil, D., Wich, S. and Wilson, K. 2009 Confronting the carbon crisis - a safeguard for tropical forest wildlife. Conservation Letters 2 : 123-129.

Wakker, E. 2005 Greasy palms: the social and ecological impacts of large-scale oil palm plantation development in Southeast Asia. Friends of the Earth, London.

Walker, R.T., Browder, J.O., Arima, E., Simmons, C.S., Pereira, R., Caldas, M., Shirota, R. and Zen, S. 2009 Ranching and the new global range: Amazônia in the 21st century. Geoforum 40(5): 732-745.

World Bank. World development indicators. http://go.worldbank.org/6HAYAHG8H0 [25 February 2010]. 


CIFOR Occasional Papers contain research results that are significant to tropical forestry. The content is peer reviewed internally and externally.

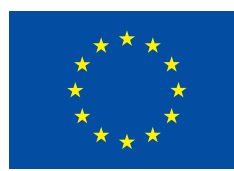

CIFOR advances human wellbeing, environmental conservation and equity by conducting research to inform policies and practices that affect forests in developing countries. CIFOR is one of 15 centres within the Consultative Group on International Agricultural Research (CGIAR). CIFOR's headquarters are in Bogor, Indonesia. It also has offices in Asia, Africa and South America. 